\section{Australian Journal of \\ Crop Science}

AJCS 11(1):63-70 (2017)

doi: 10.21475/ajcs.2017.11.01.pne234

\title{
Manganese accumulation and dry matter production of Guinea Grass (Panicum maximum) after application of increasing doses of Mn fertilizer
}

\author{
Rilner Alves Flores ${ }^{1 *}$, Virgínia Damin ${ }^{1}$, Yoná Serpa Mascarenhas ${ }^{1}$, Deyvid Diego Carvalho \\ Maranhão ${ }^{2}$, Everton Martins Arruda ${ }^{1}$, Humberto Oliveira Guimarães ${ }^{1}$, Tiago Carvalhais de Oliveira ${ }^{1}$, \\ Ana Paula Marquez Belo ${ }^{1}$, Tatiana Carvalho Faria ${ }^{1}$
}

\author{
${ }^{1}$ Department of Soil Science, Agronomy School, Federal University of Goias, Goiania, GO, Brazil \\ ${ }^{2}$ Department of Soil Science, Rural Federal University of Rio de Janeiro, Seropedica, RJ, Brazil
}

*Corresponding author: rilner1@ hotmail.com

\begin{abstract}
The manganese $(\mathrm{Mn})$ is an important nutrient to forage development; however, there is a lack of information regarding to adequate Mn-fertilizer rates for Guinea Grass (Panicum maximum) species growing in Brazilian soils. The objective of this research was to evaluate the effect of $\mathrm{Mn}$ on growth, nutrition and yield of Guinea Grass. The study was carried out under greenhouse conditions in a randomized block design, with five $\mathrm{Mn}$ rates $\left(0,15,30,60\right.$ and $\left.120 \mathrm{mg} \mathrm{dm}^{-3}\right)$ and four replicates, using manganese sulfate $(35.5 \%$ $\mathrm{Mn}$ ) as Mn source. Plant's growth parameters, dry mass production, $\mathrm{Mn}^{2+}$ levels and accumulation in plant's tissues were measured and $\mathrm{Mn}$ efficiencies of absorption, transport and utilization were calculated. Enhancing Mn doses, there was a proportional increase of $\mathrm{Mn}^{2+}$ levels in the leaves and the roots. Regarding to the growth parameters, the number of leaves and both root and aboveground dry mass were slightly affected by Mn application. The highest Mn efficiency of absorption and transport by Guinea Grass was ob using $30 \mathrm{mg} \mathrm{dm}$ of $\mathrm{Mn}$; however, the Mn utilization efficiency was higher when Mn was not applied. In this way, the Mn fertilization in Guinea Grass is economically viable using doses up to $30 \mathrm{mg} \mathrm{dm}^{-3}$.
\end{abstract}

Keywords: Micronutrients; pastures; phytotoxicity; fertilization; plant nutrition.

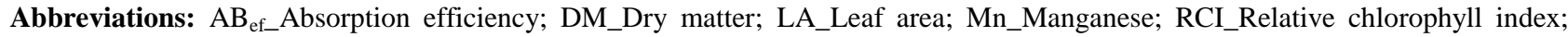

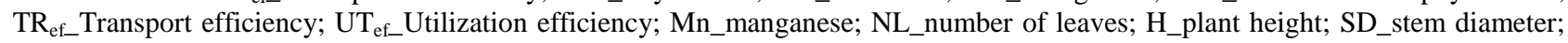
RDM_Root dry matter; SDM_Shoot dry matter; NP_power neutralization; RPTN_Relative Neutralization Total Power; DAS_days after sowing.

\section{Introduction}

The cultivation of Panicum gender has increased in recent years, due to its high dry matter yield potential (Braz et al., 2010), high adaptability, forage quality and ease establishment (Mingotte et al., 2011). However, several factors may limit the achievement of high yields, especially the occurrence of nutritional imbalances. Micronutrients are essential elements for plant growth and development, although they are required in small amounts, their imbalance can impair production (Malavolta, 2006). Manganese (Mn), for example, is found in concentrations ranging from 20 up to $3000 \mathrm{mg} \mathrm{kg}$, with average values around $350 \mathrm{mg} \mathrm{kg}^{-1}$ (Malavolta, 1980). Mn exerts many functions in plants, integrating processes related to protein synthesis, membrane permeability, ion absorption, respiration, starch synthesis and hormonal control (Teixeira et al., 2005). This micronutrient is a cofactor in enzymatic reactions, and an enzyme constituent involved in the water photolysis in photosystem II (Malavolta, 2006; Peiter et al., 2007). Plant species with nutrient deficiency have reduced root growth (Prado, 2008) and, consequently, lower crop yields. On the other hand, in high concentrations it may be toxic (Doyle et al., 2003), conditioning morphological (Arruda et al., 2016.) and biochemical disorders in vegetables (Lidon et al., 2004; Millaleo et al., 2010; Marschner, 2012; Millaleo et al., 2013), and in forages, can trigger animal poisoning after ingestion (Prado, 2008). The main factors driving the Mn availability in soils are $\mathrm{pH}$, redox potential, organic matter content and balance with other soil cations (Prado, 2008). Decreasing soil $\mathrm{pH}$ bellow 5.0, there are an increase in the $\mathrm{Mn}$ soluble compounds, which may is toxic to the living organisms, including plants. However, the nutrient toxicity may occur at higher $\mathrm{pH}$ soils as we, if there are reducing conditions caused by water saturation, soil compaction or accumulation of organic matter (Foy et al., 1978). The Mn availability is determined by the element reactions in soil; $\mathrm{Mn}^{2+}$ to be oxidized reaches $\mathrm{M}^{4+}$ form, and then precipitates as oxides and hydroxides, becoming unavailable to plants (Borkert, 1991; Herndon et al., 2015). Despite the importance of this nutrient in plant nutrition, adequate $\mathrm{Mn}$ levels have not yet been established for the development of Guinea Grass, a specie widely used in animal feed. Adequate Mn rates can increase both production and forage quality, and consequently, enhance livestock production. Thus, the aim of this study was to evaluate the effect of manganese rates applied into the soil on growth, nutrition and dry matter production of Guinea Grass. 


\section{Results and Discussion}

\section{Height, leaf area and stem diameter}

The application of increasing Mn rates into the soil affected the number of leaves (NL) of Guinea Grass, either at the first or at the second cut of the forage (Table 1). In both cases, there was quadratic adjustment, and the maximum number of leaves obtained at the first cut was 6.51 per plant, using 49.67 $\mathrm{mg} \mathrm{dm}{ }^{-3}$ of $\mathrm{Mn}$, and 4.32 per plant with $75.83 \mathrm{mg} \mathrm{dm}^{-3}$ of $\mathrm{Mn}$, at the second cut. At the second cut increasing Mn rates reduced NL by $28.5 \%$ (Fig 1). Mn rates, which showed average values of 13.15 and $14.78 \mathrm{~cm}$ for plant height $(\mathrm{H})$, and 1.17 and $2.28 \mathrm{~cm}$ for stem diameter (SD), at the first and second cuts, respectively, did not affect the others growth parameters evaluated.

High Mn accumulation can reduce leaf biomass (Saidi et al., 2014) and plant growth (Shenker et al., 2004) due to degradative process (Shenker et al., 2004; Papadakis et al., 2007, Marschner, 2012), chlorophylls synthesis reduction (Lidon et al., 2004; Wang et al., 2009) and low carboxylation (Millaleo et al., 2010; Millaleo et al., 2013). Thus, Mn interferes with the photosynthetic performance (Kitao et al., 1997; Nable et al., 1988; Vitti et al., 2006; Schmidt et al., 2013), and its excess can potentiate reactions with oxygen, causing damage cells (Papadakis et al., 2007), directly affecting the operation of photosystem II, responsible for water photolysis (Dechen and Nachtigall, 2007).

\section{$\mathrm{Mn}^{2+}$ content in roots and shoot}

There was an increase in the $\mathrm{Mn}^{2+}$ content in leaves and roots with increasing rates applied (Table 2). The nutrient content was 233.51 and $175.31 \mathrm{mg} \mathrm{kg}^{-1}$ in the shoot (first cut) and roots (second cut), respectively, fallowing the highest rate $\left(120 \mathrm{mg} \mathrm{dm}^{-3}\right.$ ) application (Fig 2). The $\mathrm{Mn}^{2+}$ content in the shoot at the second cut showed quadratic adjustment due to the application of $\mathrm{Mn}^{2+}$ increasing rates, with the maximum content of $568.74 \mathrm{mg} \mathrm{kg}^{-1}$ obtained with $81.64 \mathrm{mg} \mathrm{dm}^{-3}$ (Fig 2). Cavalcante et al. (2013) found plants of Urochloa brizantha cv. MG5 not showing significant effects at the second cut, when subjected to Mn similar rates used in this study.

The increases in the $\mathrm{Mn}^{2+}$ content were approximately 19 , 74 and $39 \%$ in the shoot, at the first and at the second cut, and in the root at the second cut compared with the initial contents of 196; 327 and $126 \mathrm{mg} \mathrm{kg}^{-1}$, respectively.

These results are similar to those observed by Arruda et al., (2016), who showed higher concentrations of $\mathrm{Mn}^{2+}$ in Urochloa humidicula at the second cut. They attributed this increase in $\mathrm{Mn}^{2+}$ concentration to the greater root development compared with the first cut, which favored the nutrient absorption (Arruda et al., 2016). Guirra et al. (2011) and Sylvestre et al. (2012) observed the same pattern when assessing the effect of $\mathrm{Mn}$ in Tanzania grass (Panicum maximum) and Urochloa brizantha cv. Marandu, attributing the highest nutrient levels to the development of the root system.

Some authors suggest that high Mn concentrations at the middle of the plant growth period imply in higher accumulation of nutrients in the shoot. In fact, Lidon (2001) observed increases in the $\mathrm{Mn}^{2+}$ content in plant tissue, when evaluating Oryza sativa L. cv. Safari at the beginning of the growth period. However, plants may have regulatory mechanisms when subjected to high $\mathrm{Mn}$ concentrations (Lidon and Teixeira, 2000), which gives some grass species tolerance to high Mn concentrations (Paschke et al., 2005).
Although $\mathrm{Mn}^{2+}$ is absorbed by root interception (Prado, 2008), its absorption can also be passive when high concentrations of this nutrient are present in the soil solution (Dechen and Nachtigall, 2007; Yasuor et al., 2015). Some authors suggest that nitrogenous ammonia-based fertilizations may condition soil $\mathrm{pH}$ reductions (Ducic and Polle, 2005), as a result of the ammonium transformation process in nitrate (Cantarella et al., 2007), and consequently, increasing the availability of $\mathrm{Mn}^{2+}$ in the solution (Smith and Paterson, 1990; Freitas et al., 2007). This process may explain the $\mathrm{Mn}^{2+}$ increase in the shoot from the first to the second cut (Sylvestre et al., 2012; Arruda et al., 2016), whereas spaced fertilizations of urea were conducted using rates of $100 \mathrm{mg}$ $\mathrm{dm}^{-3}$ of $\mathrm{N}$ at sowing and $50 \mathrm{mg} \mathrm{dm}^{-3} 30$ days after.

\section{Dry matter production}

The application of increasing $\mathrm{Mn}$ rates raised shoot dry matter production (SDM) up to the $60 \mathrm{mg} \mathrm{dm}^{-3}$ rate (Table 3), followed by a decrease at the $120 \mathrm{mg} \mathrm{dm}^{-3}$ rate at the first cut. At the second cut, the highest dry mass production $(8.38 \mathrm{~g}$ per plant) was achieved without Mn. Root dry matter (RDM) showed similar results to those of SDM at the first cut, with higher production at the rate of $60 \mathrm{mg} \mathrm{dm}^{-3}$, around $0.62 \mathrm{~g}$ per plant, followed by a decrease of $54.84 \%$ in production. While shoot dry mass production was high without the application of Mn, being $23.84 \%$ higher when compared with the production of the corresponding rate of $15 \mathrm{mg} \mathrm{dm}^{-3}$.

Quadratic adjustments were verified in SDM and RDM parameters at the second cut, with values of $5.86 \mathrm{~g}$ per plant for SDM and $0.47 \mathrm{~g}$ per plant for RDM at the rates 68.25 and $57.50 \mathrm{mg} \mathrm{dm}^{-3}$ (Fig 3). In contrast to the results obtained at the second cut, Mn rates applied did not affect the production of SDM at the first cut.

The increases observed in shoot, root and whole plant dry matter production are attributed to increased photosynthetic rate, due to the necessary $\mathrm{Mn}$ absorption for the metabolic functions of plant (Schmidt et al., 2013; Arruda et al., 2016). However, the excess of exchangeable $\mathrm{Mn}$ in the soil promotes biochemical disturbances that can reduce the plant biomass production (Papadakis et al., 2007; Millaleo et al., 2010; Millaleo et al., 2013), as observed at the highest rates applied.

To evaluate the effect of $\mathrm{Mn}$ fertilizer rates in the production of Urochloa Brizantha, Puga et al. (2011) observed that the rate of $120 \mathrm{mg} \mathrm{dm}^{-3}$ favored $\mathrm{Mn}$ accumulation in the leaves of the grass, without harming dry matter production. Some authors observed reduction in dry matter production and root development (Saidi et al., 2014) and associated this effect to the reduction of chlorophylls, linked to Mn excess (Lindon et al., 2004) and to photosynthetic rate decrease (Wang et al., 2009; Marschner, 2012), as well as reduction of carbohydrate synthesis (Mingotte et al., 2011).

\section{$\mathrm{Mn}^{2+}$ accumulation in roots and shoot}

The increased supply of this nutrient to the soil raised $\mathrm{Mn}^{2+}$ levels in shoots and roots of Guinea Grass at both cuts (Table 4), except for the effect of the highest Mn rate on the roots dry mass (RDM). The nutrient contents were 233.51 and $175.31 \mathrm{mg} \mathrm{kg}^{-1}$ in shoots at the first cut and in the roots at the second cut, with the application of the highest rate $(120 \mathrm{mg}$ $\left.\mathrm{dm}^{-3}\right)$, with quadratic adjustment regarding the content of $\mathrm{Mn}^{2+}$ at the first and second cuts, followed by a maximum content of 0.17 and $2.45 \mathrm{mg} \mathrm{kg}^{-1}$ with 70 and $107.5 \mathrm{mg} \mathrm{dm}^{-3}$ (Fig 4). While at the second cut an increment of accumulated $\mathrm{Mn}^{2+}$ in the roots was observed, followed by a quadratic 
Table 1. Height (H), stalk diameter (SD) and number of leaves (NL) of Guinea Grass, according to the application of manganese in the soil.

\begin{tabular}{|c|c|c|c|c|c|c|}
\hline \multirow[t]{2}{*}{ Rates of Manganese } & \multicolumn{3}{|c|}{ First CUT } & \multicolumn{3}{|c|}{ Second cut } \\
\hline & Height & $\mathrm{SD}$ & NL & Height & $\mathrm{SD}$ & NL \\
\hline $\mathrm{mg} \mathrm{dm}^{-3}$ & $\mathrm{~cm}$ & $\mathrm{~cm}$ & planta $^{-1}$ & $\mathrm{~cm}$ & $\mathrm{~cm}$ & planta $^{-1}$ \\
\hline 0 & 12.85 & 1.19 & 5.55 & 15.65 & 2.17 & 6.60 \\
\hline 15 & 13.07 & 1.10 & 6.55 & 13.85 & 2.34 & 4.60 \\
\hline 30 & 13.30 & 1.20 & 6.35 & 15.82 & 2.41 & 4.95 \\
\hline 60 & 13.70 & 1.08 & 6.55 & 15.35 & 2.04 & 4.80 \\
\hline 120 & 12.82 & 1.26 & 5.75 & 15.25 & 2.42 & 4.95 \\
\hline F test & $1.14^{\mathrm{ns}}$ & $0.22^{\mathrm{ns}}$ & $18.59 * *$ & $1.02^{\mathrm{ns}}$ & $1.46^{\mathrm{ns}}$ & $4.29 *$ \\
\hline C.V. (\%) & 5.16 & 26.58 & 3.54 & 10.19 & 11.94 & 15.04 \\
\hline${ }^{1} \mathrm{LR}$ & $0.07^{\mathrm{ns}}$ & $0.14^{\mathrm{ns}}$ & $1.35^{\mathrm{ns}}$ & $0.05^{\mathrm{ns}}$ & $0.45^{\mathrm{ns}}$ & $3.19^{\mathrm{ns}}$ \\
\hline${ }^{2} \mathrm{QR}$ & $4.34^{\mathrm{ns}}$ & $0.34^{\mathrm{ns}}$ & $54.50 * *$ & $0.01^{\mathrm{ns}}$ & $0.68^{\mathrm{ns}}$ & $6.41^{*}$ \\
\hline
\end{tabular}

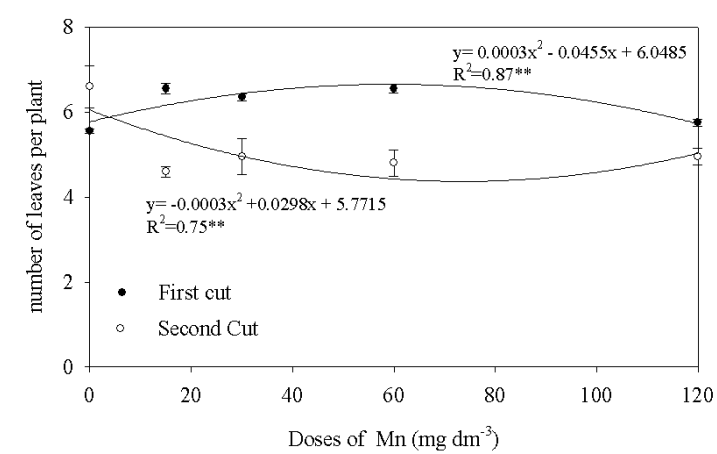

Fig 1. Number of leaves per plant of Guinea Grass in the first and second cut forage, according to the application of manganese in the soil. ** and * - significant at the 1 and $5 \%$ level probability by the $\mathrm{F}$ test, respectively.

Table 2. Manganese content in plants of Guinea Grass in the aerial part at the first and second cuts and the second cut roots, according to the application of manganese in the soil.

\begin{tabular}{lccc}
\hline \multirow{2}{*}{ Rates of Manganese } & First cut & \multicolumn{2}{c}{ Second cut } \\
\cline { 2 - 4 } \cline { 3 - 4 } $\mathrm{mg} \mathrm{dm}^{-3}$ & Aerial Part & Aerial Part & Roots \\
0 & 188.25 & -105.75 \\
15 & 203.25 & 283.25 & 136.75 \\
30 & 211.00 & 472.50 & 153.75 \\
60 & 221.75 & 477.25 & 159.25 \\
120 & 228.75 & 519.75 & 166.50 \\
\hline F test & $7.99^{* *}$ & 522.00 & $26.98^{* *}$ \\
C.V. $(\%)$ & 5.33 & $88.36^{*}$ & 6.46 \\
${ }^{1} \mathrm{LR}$ & $26.64^{* *}$ & 4.62 & $61.35^{* *}$ \\
${ }^{2} \mathrm{QR}$ & $4.96^{*}$ & $166.78^{* *}$ & $1.70^{\mathrm{ns}}$ \\
\hline
\end{tabular}

${ }^{1}$ Linear regression; ${ }^{2}$ Quadratic regression; ${ }^{\text {n.s. }}, *, * *-$ not significant, significant at the $5 \%$ and significant at the $1 \%$ level probability by the F test.

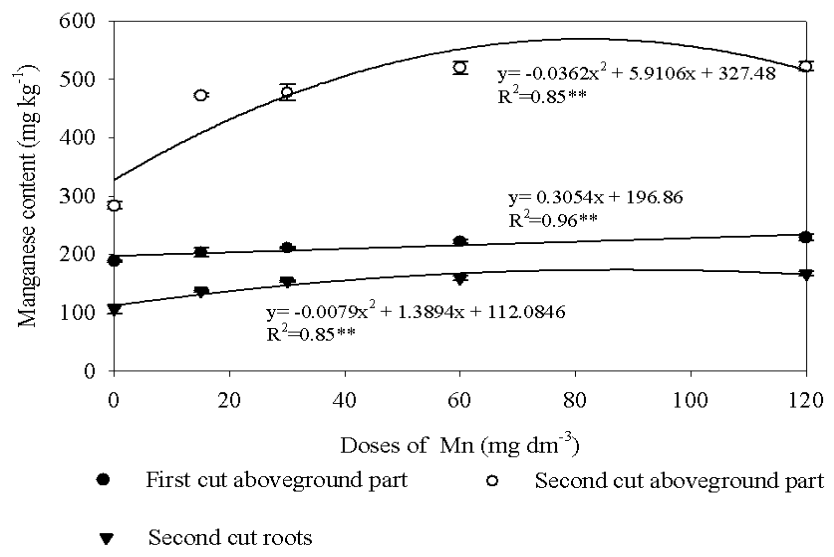

Fig 2. Manganese content in plants of Guinea Grass in the aerial part at the first and second cuts, and second cut roots, according to the application of manganese in the soil. ** - significant at the $1 \%$ level probability by the $\mathrm{F}$ test. 
Table 3. Dry matter production in plants of Guinea Grass in the aerial part at the first and second cuts, in the roots of the second cut and total aerial parts forage, according to the application of manganese in the soil.

\begin{tabular}{|c|c|c|c|c|}
\hline \multirow[b]{2}{*}{ Rates of Manganese } & \multirow{2}{*}{$\begin{array}{c}\text { First cut } \\
\text { Dry matter } \\
\text { Aerial Part }\end{array}$} & \multicolumn{2}{|c|}{ Second CUT } & \multirow{2}{*}{$\begin{array}{c}\text { Total } \\
\text { Dry matter } \\
\text { Aerial Part }\end{array}$} \\
\hline & & $\begin{array}{l}\text { Dry matter } \\
\text { Aerial Part }\end{array}$ & $\begin{array}{l}\text { Dry matter } \\
\text { roots }\end{array}$ & \\
\hline $\mathrm{mg} \mathrm{dm}^{-3}$ & & - & 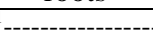 & \\
\hline 0 & 0.89 & 8.38 & 0.34 & 9.27 \\
\hline 15 & 1.02 & 6.04 & 0.37 & 7.06 \\
\hline 30 & 1.14 & 6.33 & 0.26 & 7.47 \\
\hline 60 & 1.28 & 6.27 & 0.62 & 7.55 \\
\hline 120 & 1.23 & 6.43 & 0.28 & 7.66 \\
\hline F test & $2.4^{\mathrm{ns}}$ & $4.22 *$ & $11.57 * *$ & $3.08^{*}$ \\
\hline C.V. $(\%)$ & 18.48 & 13.88 & 22.47 & 12.38 \\
\hline${ }^{1} \mathrm{LR}$ & $6.03 *$ & $3.08^{\mathrm{ns}}$ & $0.96^{\mathrm{ns}}$ & $1.36^{\mathrm{ns}}$ \\
\hline${ }^{2} \mathrm{QR}$ & $3.60^{\mathrm{ns}}$ & $6.51 *$ & $17.80^{* *}$ & $4.20^{\mathrm{ns}}$ \\
\hline
\end{tabular}

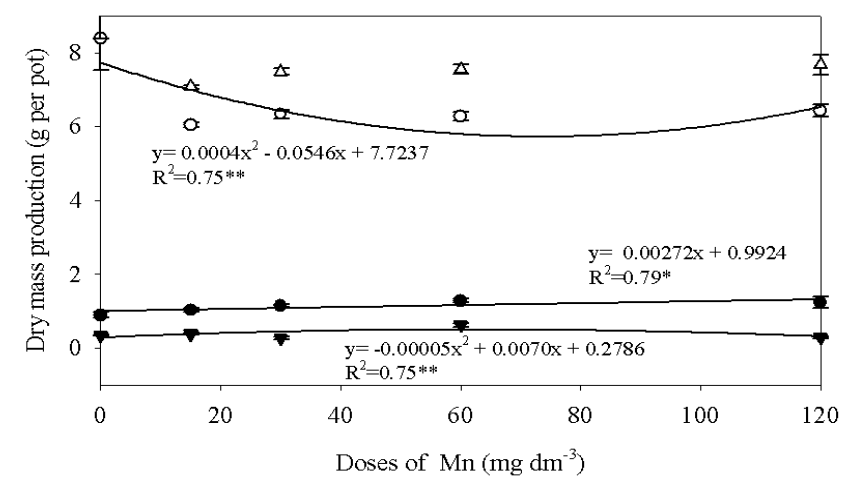

$\begin{array}{llll}\text { - First cut aboveground part } & \diamond & \text { Second cut aboveground part } \\ \text { - Second cut roots } & \Delta & \text { Cumulative aboveground part }\end{array}$

Fig 3. Dry matter production in plants of Guinea Grass in the aerial part at the first and second cuts, in the roots of the second cut and total aerial part forage, according to the application of manganese in the soil.

$*$ and ** - significant at the 5 and $1 \%$ level probability by the $\mathrm{F}$ test.

Table 4. Manganese accumulation in plants of Guinea Grass in the aerial part at the first and second cuts, in the roots of the second cut and total aerial part forage, according to the application of manganese in the soil.

\begin{tabular}{|c|c|c|c|c|}
\hline \multirow{2}{*}{ Rates of Manganese } & \multirow{2}{*}{$\begin{array}{c}\text { First cut } \\
\text { Aerial Part }\end{array}$} & \multicolumn{2}{|c|}{ Second CUT } & \multirow{2}{*}{$\begin{array}{c}\text { Total } \\
\text { Aerial Part }\end{array}$} \\
\hline & & Aerial Part & Roots & \\
\hline $\mathrm{mg} \mathrm{dm}$ & & - & 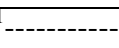 & \\
\hline 0 & 0.17 & 2.37 & 0.04 & 2.54 \\
\hline 15 & 0.21 & 2.86 & 0.05 & 3.07 \\
\hline 30 & 0.24 & 3.02 & 0.04 & 3.26 \\
\hline 60 & 0.28 & 3.25 & 0.10 & 3.53 \\
\hline 120 & 0.28 & 3.35 & 0.05 & 3.63 \\
\hline F Test & $5.15 * *$ & $8.18 * *$ & $12.80 * *$ & $9.28 * *$ \\
\hline C.V. $(\%)$ & 18.58 & 9.16 & 26.22 & 4.30 \\
\hline${ }^{1} \mathrm{LR}$ & $14.83 * *$ & $23.59 * *$ & $3.61^{\mathrm{ns}}$ & $26.88 * *$ \\
\hline${ }^{2} \mathrm{QR}$ & $5.76^{*}$ & $7.84 *$ & $28.06 * *$ & $9.09 * *$ \\
\hline
\end{tabular}

Table 5. Absorption efficiency, transport efficiency and utilization efficiency of manganese in plants of Guinea Grass, according to the application of manganese in the soil.

\begin{tabular}{|c|c|c|c|}
\hline Rates of Manganese & Absorption efficiency & $\begin{array}{l}\text { Transport } \\
\text { Efficiency }\end{array}$ & $\begin{array}{l}\text { Utilization } \\
\text { Efficiency }\end{array}$ \\
\hline $\mathrm{mg} \mathrm{dm}{ }^{-3}$ & $\mathrm{mg} \mathrm{g}^{-1}$ & $\%$ & $\mathrm{mg} \mathrm{g}^{-1}$ \\
\hline 0 & 7.67 & 98.58 & 35.99 \\
\hline 15 & 8.59 & 98.36 & 17.79 \\
\hline 30 & 15.30 & 98.75 & 18.20 \\
\hline 60 & 6.02 & 97.25 & 18.39 \\
\hline 120 & 13.39 & 98.71 & 17.16 \\
\hline F test & $2.92^{\mathrm{ns}}$ & $8.14^{* *}$ & $18.39 * *$ \\
\hline C.V. $(\%)$ & 45.46 & 0.44 & 17.59 \\
\hline${ }^{1} \mathrm{LR}$ & $1.42^{\mathrm{ns}}$ & $0.08^{\text {ns }}$ & $23.14 * *$ \\
\hline${ }^{2} \mathrm{QR}$ & $0.14^{\mathrm{ns}}$ & $15.24 * *$ & $23.44 * *$ \\
\hline
\end{tabular}




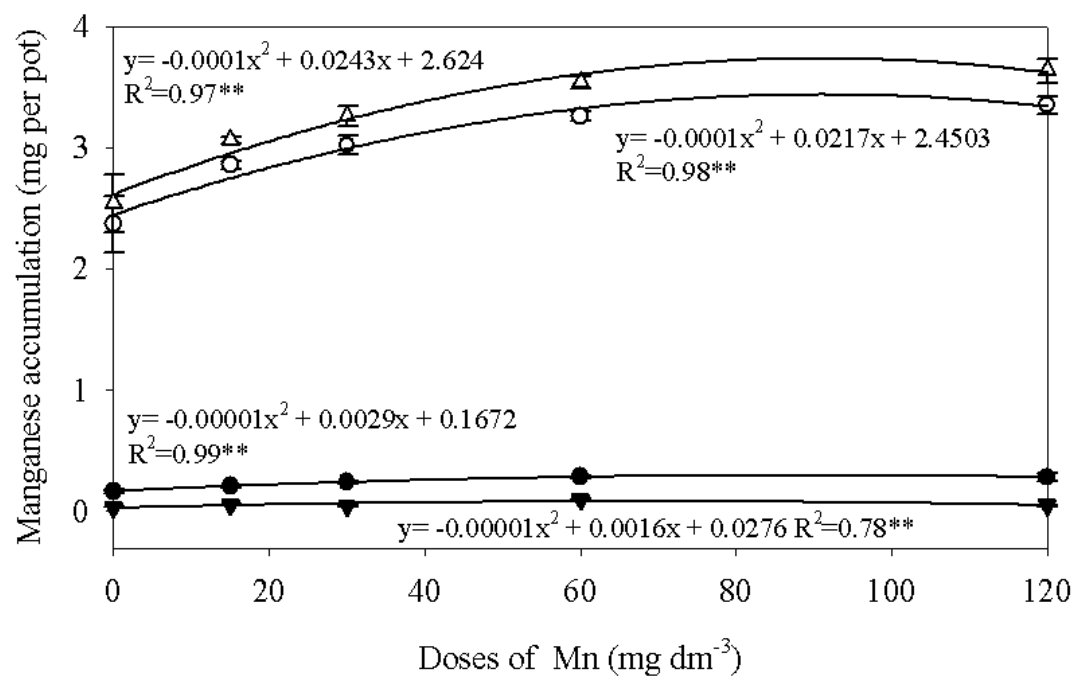

- First cut aboveground part $\quad \circ$ Second cut aboveground part

$\nabla$ Second cut roots $\Delta$ Cumulative aboveground part

Fig 4. Manganese accumulation in plants of Guinea Grass in the aerial part at the first and second cuts, in the roots of the second cut and total aerial part forage, according to the application of manganese in the soil.

$*$ and $* *$ - significant at the 5 and $1 \%$ level probability by the $\mathrm{F}$ test.

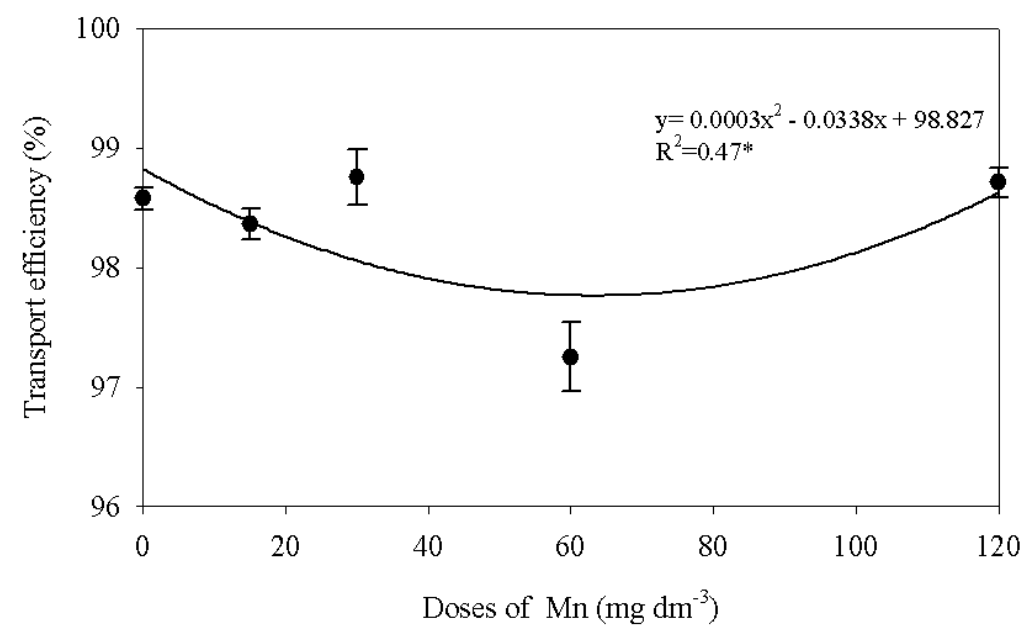

Fig 5. Transport efficiency of manganese in plants of Guinea Grass, according to the application of manganese in the soil. ** - significant at the $1 \%$ level probability by the $\mathrm{F}$ test.

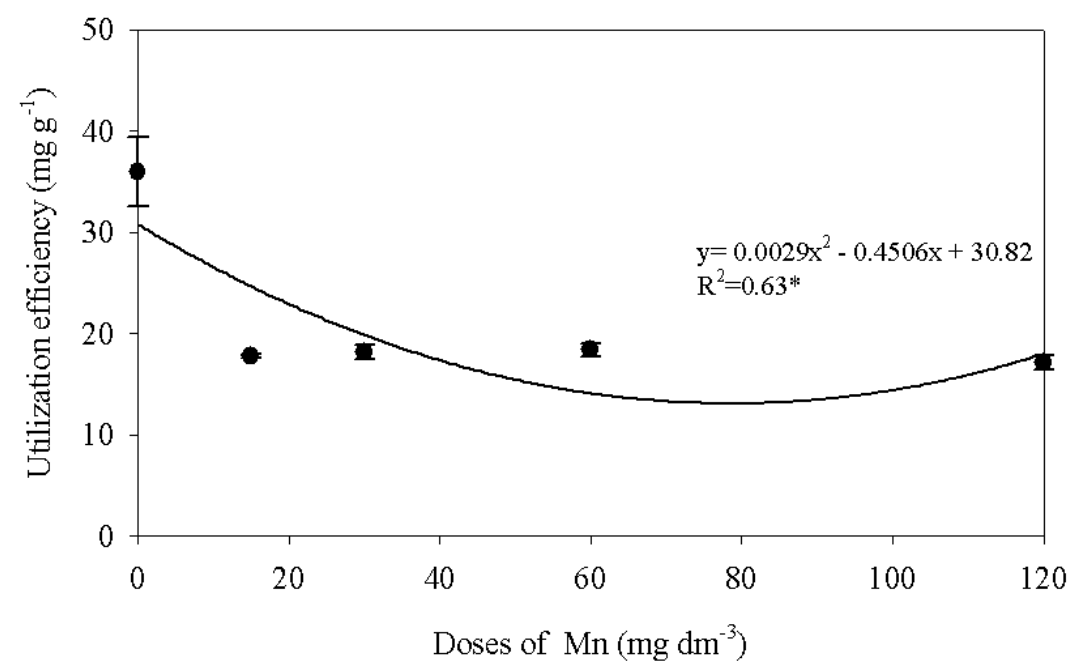

Fig 6. Utilization efficiency of manganese in plants of Guinea Grass, according to the application of manganese in the soil. ** - significant at the $1 \%$ level probability by the $\mathrm{F}$ test. 
adjustment $(\mathrm{p}<0.05)$ of $0.087 \mathrm{mg} \mathrm{kg}^{-1}$ at the rate of $75 \mathrm{mg} \mathrm{kg}$ ${ }^{1}$ of $\mathrm{Mn}$. $\mathrm{Mn}^{2+}$ accumulation in plants was approximately 80; 26 and $61 \%$ in the shoots at the first and second cuts, and in the roots at the second cut, compared with the initial content of $196 ; 327$ and $126 \mathrm{mg} \mathrm{kg}^{-1}$, respectively. The distribution of $\mathrm{Mn}^{2+}$ may occur through active transport in epidermal root cells and then it is absorbed in divalent form $\left(\mathrm{Mn}^{2+}\right)$ and redistributed in the plant (Gherardi and Rengel, 2004; Pittman, 2005). The $\mathrm{Mn}^{2+}$ absorption by roots is characterized as a two-phase process, involving the primary transport to the xylem, and transference from the xylem to the phloem (Humphries et al., 2007).

However, low $\mathrm{Mn}^{2+}$ phloem mobility, as well as the redistribution depends on the plant species and stage of development (Herren and Feller, 1994); therefore, the accumulation of nutrients in the tissue is related to the amount of exchangeable $\mathrm{Mn}^{2+}$ in the soil solution; thus controlling absorption and accumulation. In view of some aspects related to the use of forage in animal production, $\mathrm{Mn}^{2+}$ accumulation should be monitored, as high rates can be harmful to animals, affecting the integrity of sperm and acrosome plasma membranes (Reis et al., 2014), which can reduce the reproductive capability of the bull. On the other hand, Carvalho et al. (2010) reported that Mn deficiency affects embryogenesis, causing poor reproductive formation and birth of calves with congenital defects in skeletal and articulate tissues. Thus, $\mathrm{Mn}^{2+}$ content cumulus in plants is important, both in biomass production in forage, as in livestock production, whereas imbalances can cause deleterious effects.

\section{Efficiency indices: Absorption, transport and utilization}

Guinea Grass plants showed better absorption and transport efficiency when $30 \mathrm{mg} \mathrm{kg}^{-1}$ of $\mathrm{Mn}$ was applied, with absorption efficiency values of $15.30 \mathrm{mg} \mathrm{g}^{-1}$ and $98.75 \%$ transport efficiency, contrasting with the rate of $60 \mathrm{mg} \mathrm{kg}^{-1}$ of $\mathrm{Mn}$, with values of $6.02 \mathrm{mg} \mathrm{g}^{-1}$ and $97.25 \%$ of those parameters, respectively, which were the lowest values among the Mn rates evaluated. However, the control rate showed satisfactory results on the order of $35.99 \mathrm{mg} \mathrm{g}^{-1}$, corresponding to $52.32 \%$ higher than the lowest rate, regarding efficiency use. The absorption efficiency of $\mathrm{Mn}$ $\left(\mathrm{AB}_{\mathrm{ef}}\right)$ did not differ among the evaluated $\mathrm{Mn}$ rates. In Urochloa humidicola Arruda et al., (2016) observed an enhanced $A_{\text {ef }}$ with the increase of $M n$ doses. Since this nutrient is toxic when its level is high in soil, these results suggested that Guinea Grass may is less susceptible to the toxic stress by $\mathrm{Mn}$ than Urochloa humidicola. Both $\mathrm{Mn}$ transport $\left(\mathrm{TR}_{\mathrm{ef}}\right)$ and utilization efficiency $\left(\mathrm{UT}_{\mathrm{ef}}\right)$ were affected by $\mathrm{Mn}$ rates $(\mathrm{P}<0.05)$ and showed a quadratic adjustment, wherein the models (Fig 5 and Fig 6) predict values greater than $30 \mathrm{mg} \mathrm{kg}^{-1}$ of Mn (Table 5). Despite the fact that $\mathrm{TR}_{\mathrm{ef}}$ differed among $\mathrm{Mn}$ doses, only slightly differences were observed and it may is not important agronomically. In fact, for Urochloa humidicola, Arruda et al., (2016) observed no effect of increasing $\mathrm{Mn}$ rates on $\mathrm{TR}_{\text {ef.. }}$ Regarding the $\mathrm{UT}_{\mathrm{ef}}$, it was decreased with the increase of $\mathrm{Mn}$ doses. Similar results were observed by Arruda et al. (2016). Since $30 \mathrm{mg} \mathrm{kg}^{-1}$ of $\mathrm{Mn}$ is a low fertilization rate and this fertilizer has low cost; the Mn utilization in Guinea Grass at this rate is economically viable.

\section{Materials and Methods}

\section{Growing conditions}

This research was conducted in a greenhouse at Federal University of Goias, State of Goias, Brazil, coordinates: $16^{\circ}$ $35 "$ latitude south and $49^{\circ} 21^{\prime}$ longitude west, at approximately $730 \mathrm{~m}$ of altitude and $1,600 \mathrm{~mm}$ average annual rainfall. The climate regional is Aw (mega thermal) or tropical savannah, with dry winters and rainy summers (Köppen, 1948). The soil analysis showed the following properties: $\mathrm{pH}=5.0$; Organic matter $=2.0 \mathrm{~g} \mathrm{dm}^{-3} ; \mathrm{P}=5.5 \mathrm{mg}$ $\mathrm{dm}^{-3} ; \mathrm{K}=60 \mathrm{mg} \mathrm{dm}^{-3} ; \mathrm{Ca}=2.7 \mathrm{mmol}_{\mathrm{c}} \mathrm{dm}^{-3} ; \mathrm{Mg}=0.5 \mathrm{mmol}_{\mathrm{c}}$ $\mathrm{dm}^{-3} ; \mathrm{B}=0.21 \mathrm{mg} \mathrm{dm}^{-3} ; \mathrm{Cu}=2.8 \mathrm{mg} \mathrm{dm}^{-3} ; \mathrm{Fe}=82 \mathrm{mg} \mathrm{dm}^{-3} ;$ $\mathrm{Mn}=44 \mathrm{mg} \mathrm{dm}^{-3} ; \mathrm{Zn}=4.6 \mathrm{mg} \mathrm{dm}^{-3} ; \mathrm{H}+\mathrm{Al}=1.8 \mathrm{mmol}_{\mathrm{c}} \mathrm{dm}^{-}$ ${ }^{3}$; $\mathrm{CEC}=5.2 \mathrm{mmol}_{\mathrm{c}} \mathrm{dm}^{-3}$; Base saturation $(\%)=65.1 \%$, with $432 \mathrm{~g} \mathrm{~kg}^{-1}$ of clay.

\section{Treatments and experimental design}

The treatments were as 0 (control), 15, 30, 60 and $120 \mathrm{mg}$ $\mathrm{dm}^{-3}$ of $\mathrm{Mn}$ as manganese sulfate $(35.5 \% \mathrm{Mn})$, arranged in an entirely randomized bloc design, with four replicates. Each experimental unit consisted of one $4 \mathrm{dm}^{3}$ pot, filled with 3.5 $\mathrm{dm}^{3}$ of a clayey dystrophic red Oxisol (Santos et al., 2013), drawn from the topsoil layer (0-0.2m deep).

\section{Treatments application and analysis}

Liming was performed on August 2, 2014, using calcined lime $(\mathrm{CaO}=58.5 \% ; \mathrm{MgO}=9 \% ; \mathrm{NP}=127 \% ; \mathrm{RPTN}=$ $99.4 \%$ ), to reach base saturation (V\%) equal to $80 \%$, while maintaining the moist soil mass at $60 \%$ retention capacity, and incubated for 30 days.

After the incubation period, a fertilizer solution was applied to the soil with the following rates of micronutrients: $1.5 \mathrm{mg}$ $\mathrm{dm}^{-3}$ of $\mathrm{Cu}\left(\mathrm{CuSO}_{4} .5 \mathrm{H}_{2} \mathrm{O}\right.$ p.a. $) ; 0.8 \mathrm{mg} \mathrm{dm}^{-3}$ of $\mathrm{B}\left(\mathrm{H}_{3} \mathrm{BO}_{3}\right.$ p.a.); $0.15 \mathrm{mg} \mathrm{dm}^{-3}$ of $\mathrm{Mo}\left(\mathrm{NaMoO}_{4} \cdot 2 \mathrm{H}_{2} \mathrm{O}\right.$ p.a. $) ; 4.0 \mathrm{mg} \mathrm{dm}^{-3}$ of $\mathrm{Fe}\left[\mathrm{Fe}_{2}\left(\mathrm{SO}_{4}\right)_{3} \cdot 4 \mathrm{H}_{2} \mathrm{O}\right.$ p.a. $]$ and $5.0 \mathrm{mg} \mathrm{dm}$ of $\mathrm{Zn}\left(\mathrm{ZnSO}_{4}\right.$ p.a.) (Mesquita et al., 2004). The following rates of macronutrients were also applied: $305 \mathrm{mg} \mathrm{dm}^{-3}$ of $\mathrm{P}$ as single superphosphate; $150 \mathrm{mg} \mathrm{dm}^{-3}$ of $\mathrm{N}$ as urea applied at sowing $\left(100 \mathrm{mg} \mathrm{dm}^{-3}\right.$ of $\left.\mathrm{N}\right)$ and the remaining $\left(50 \mathrm{mg} \mathrm{dm}^{-3}\right.$ of $\left.\mathrm{N}\right)$ at 30 days after, according to Mesquita et al. (2004); and 200 $\mathrm{mg} \mathrm{dm}{ }^{-3}$ of $\mathrm{K}$ (KCl p.a.) (Bonfim et al., 2004). Treatments (Mn rates) were applied to the soil surface and incorporated $10 \mathrm{~cm}$ deep at seedling emergence.

\section{Traits measured and nutritional indices}

Sowing has held on September 4, 2014, and thinning performed 10 days after emergence, leaving five plants per pot and irrigation done with deionized water by the weighing method, keeping soil moisture content at $60 \%$ retention capacity.

Plants were evaluated daily for symptoms of nutritional disorder. Two cuts were performed: the first at 60 days after sowing (DAS) and the second at 94 DAS. At 60 DAS and 94 DAS the plant's height was recorded by measuring the largest tiller from the base to the last leaf insertion, and stalk diameter was measured aid of a digital caliper, and the total number of sheets in a whole plant. 
Plant tissue samples were washed with a $0.1 \%$ detergent solution, a $0.3 \%$ acid solution and distilled water, and dried in oven at $65{ }^{\circ} \mathrm{C}$ for 48 hours for aerial part and root dry mass determinations (second cut, only). The $\mathrm{Mn}^{2+}$ contents from aerial part and root plant tissues were determined following methodology described by Bataglia et al. (1983).

From the dry matter and content of nutrients in plants data were performed the calculation of the nutritional indices comprising absorption efficiency $\left(\mathrm{AB}_{\mathrm{ef}}\right)$, translocation efficiency/transport $\left(\mathrm{TR}_{\mathrm{ef}}\right)$ and utilization efficiency of nutrients for conversion to dry matter ( $\mathrm{UT}_{\mathrm{ef}}$ ) (Prado, 2008). The calculation of these indices is below:

Equation Swiader et al. (1994):

Equation Li et al. (1991):

$$
\mathrm{AB}_{\mathrm{ef}}=\frac{\text { total nutrient conten in plant }}{\text { root dry matter }}
$$

$$
\mathrm{TR}_{\mathrm{ef}}=\frac{\text { nutrient conten in aerial part }}{\text { total nutrient conten in the plant }}
$$

Equation Siddiqi and Glass (1981):

$$
\mathrm{UT}_{\mathrm{ef}}=\frac{(\text { total dry matter produced })^{2}}{\text { total nutrient content in the plant }}
$$

\section{Statistical analysis}

Results were subjected to the analysis of variance using software Sisvar ${ }^{\circledR}$, Brazil (Ferreira, 2014) and to polynomial regression analysis. Linear and quadratic mathematical models were tested to select the one that provided the best data adjustment, based on the magnitude of the regression coefficients significance at $5 \%$ probability by the $t$ test. The maximum points were calculated by deriving the significant equations.

\section{Conclusions}

Enhancing Mn doses, there was a proportional increase of $\mathrm{Mn}^{2+}$ levels in the leaves and the roots.

Regarding to the growth parameters, the number of leaves and both root and aboveground dry mass was slightly affected by Mn application. The highest Mn efficiency of absorption and transport by was obtained using $30 \mathrm{mg} \mathrm{dm}^{-3}$ of $\mathrm{Mn}$, however, the Mn utilization efficiency was higher when Mn was not applied. In this way, the Mn fertilization in Guinea Grass is recommended using doses up to $30 \mathrm{mg} \mathrm{dm}^{-3}$.

\section{Acknowledgements}

We appreciate to the course postgraduate in Agronomy, soil concentration area and water, from the Federal University of Goias (UFG), and the following Brazilian institutions for financial support: FAPEG, CAPES and CNPq.

\section{References}

Arruda EM, Flores RA, Damin V, Gonçalves RA, Santos CLR, Zucchi MR, Gonçalves GMO, Barbosa RAF (2016) Growth, nutrition and production of dry matter of Kikuyu Grass (Brachiaria humidicula) as a function of $\mathrm{Mn}-$ fertilizer. Aust J Crop Sci. 10(4):556-564. doi:10.21475/ajcs.2016.10.04.p7364x

Bataglia OC, Furlani AMC, Teixeira JPF, Furlani PR (1983) Métodos de análise química de plantas. Instituto Agronômico, Boletim Técnico, Campinas. p 48.

Bonfim EMS, Freire FJ, Santos MVF, Silva TJA, Freire MBGS (2004) Soil and plant phosphorus critical levels for Brachiaria brizantha related to physical and chemical characteristics of soils in the state of Pernambuco, Brazil. Rev Bras Ci Solo. 28:281-288.

Borkert CM (1991) Manganês. In: Ferreira ME, Cruz MCP. (eds.). Micronutrientes na agricultura. Potafos/CNPq, Piracicaba.

Braz AJBP, Kliemann HJ, Silveira PM (2010) Produtividade de palhada de plantas de cobertura. In: Silveira PM, Stone LF (eds). Plantas de cobertura dos solos do cerrado. Embrapa Arroz e Ffeijão, Santo Antônio de Goiás.

Cantarella H (2007) Nitrogênio. In: Novais RF, Alvarez VVH, Barros NF, Fontes RLF, Cantarutti RB, Neves JCL (eds). Fertilidade do solo. Sociedade Brasileira de Ciência do Solo, Viçosa.

Carvalho PR, Pita MCG, Loureiro JE, Tanaka HR, Ribeiro JCS (2010) Manganese deficiency in bovines: Connection between manganese metallo enzyme dependent in gestation and congenital defects in newborn calves. Pak $\mathrm{J}$ Nutr. 9:488-503.

Cavalcante VS, Caione G, Souza LFG, Prado RM, Wamser AF (2013) Tolerance of Urochloa brizantha cv. MG5 to Mn Toxicity. Open J Soil Sci. 3:379-383.

Dechen AR, Nachtigall GR (2007) Elementos requeridos à nutrição de plantas. In: Novais RF, Alvarez VVH, Barros NF, Fontes RLF, Cantarutti RB, Neves JCL (eds). Fertilidade do Solo. Sociedade Brasileira de Ciência do Solo, Viçosa.

Doyle CJ, Pablo F, Lim RP, Hyne RV (2003) Assessment of metal toxicity in sedment pore water from Lake Macquarie, Australia. Environ Contam Toxicology. 44:343-350.

Ducic T, Polle A (2005) Transport and detoxification of manganese and copper in plants. Braz J Plant Phys. 17:103112.

Ferreira DF (2014) Sisvar: a Guide for its bootstrap procedures in multiple comparisons Ciênc Agrotec. 6:3641.

Freitas KR, Rosa B, Ruggiero JA, Nascimento JL, Heinemam AB, Macedo RF, Naves MAT, Oliveira IP (2007) Avaliação da composição química - bromatológica do capim mombaça (Panicum maximum Jacq.) submetido a diferentes doses de nitrogênio. Biosci J. 23:1-10.

Foy CD, Chaney RL, White MC (1978) The physiology of metal toxicity in plants. Annu Rev Plant Physiol. 29(3):511-566.

Gherardi M, Rengel Z (2004) The effect of manganese supply on exudation of carboxylates by roots of lucerne (Medicago sativa). Plant Soil. 260:271-282.

Guirra APPM, Fiorentin CF, Prado RM, Caetano MCT, Felici AC (2011) Tolerance of marandu grass to doses ofmanganese. Biosc J. 27:413-419.

Herndon EM, Jin L, Andrews DM, Eissenstat DM, Brantley SL (2015) Importance of vegetation for manganese cycling in temperate forested watersheds. Global Biogeochem Cycles. 29:160-174.

Herren T, Feller U (1994) Transfer of zinc from xylem to phloem in the peduncle of wheat. J Plant Nutr. 17:15871598.

Humphries J, Stangoulis J, Graham R (2007) Manganese. In: Barker A, Pilbeam D (eds). Handb Plant Nutr. Taylor and Francis, USA.

Köppen W (1948) Climatology: Common studio de los climates tierra. Fonda Cultura Económica, México.

Kitao TT, Lei T, Koike L (1997) Comparison of photosynthetic responses to manganese toxicity of deciduous broad-leaved tresin northern Japan. Environ Pollut. 97:113-118. 
Li B, McKeand SE, Allen HL (1991) Genetic variation in nitrogen use efficiency of loblolly pine seedings. Forest Sci. 37:613-626.

Lidon FC, Barreiro MG, Ramalho JR (2004) Manganese accumulation in rice: implications for photosynthetic functioning. J Plant Physiol. 161:1235-1244.

Lidon FC (2001) Tolerance of rice to excess manganese in the early stages of vegetative growth. Characterisation of manganese accumulation. J Plant Physiol. 158:1341-8.

Lidon FC, Teixeira MG (2000) Rice tolerance to excess Mn: implications in the chloroplast lamellae and synthesis of a novel Mn-protein. Pl Physiol Biochem. 38:969-78.

Malavolta E (1980) Elementos de nutrição mineral de plantas. Editora Agronômica Ceres. São Paulo.

Malavolta E (2006) Manual de nutrição mineral de plantas. Editora Agronômica Ceres. São Paulo.

Marschner P (2012) Marschner's mineral nutrition of higher plants. Academic Press, Boston.

Mesquita EE, Pinto JC, Furtini Neto E, Santos IPA, Tavares VB (2004) Critical phosphorus concentrations in three soils for the establishment of mombaça grass. R Bras Zootec. 33:290-301.

Millaleo R, Reyes-Díaz M, Ivanov AG, Mora ML, Alberdi M (2010) Manganese as essential and toxic element for plants: transport, accumulation and resistance mechanisms. J Soil Sci Plant Nutr. 10:476-494.

Millaleo R, Reyes-Díaz M, Alberdi M, Ivanov AG, Krol M, Huner NPA (2013) Excess manganese differentially inhibits photosytem I versus II in Arabidopsis thaliana. J Exp Bot. 64:343-354.

Mingotte FLC, Santos CLR, Prado RM, Flores RA, Togoro AH, Silva JAS, Politi LS, Pinto AS, Aquino DS (2011) Manganese in the nutrition and dry mass production of the mombaça grass. Biosc J. 27:879-887.

Nable RO, Houtz RL, Cheniae GM (1988) Early inhibition of photosynthesis during development of $\mathrm{Mn}$ toxicity in tobacco, Plant Physiol. 86:1136-1142.

Papadakis IE, Giannakoula A, Therios IN, Bosabalidis AM, Moustakas M, Nastou A (2007) Mn-induced changes in leaf structure and chloroplast ultra structure of Citrus volkameriana (L.) plants. J Plant Physiol. 164:100-103.

Paschke MW, Valdecantos A, Redente EF (2005) Manganese toxicity thresholds for restoration grass species. Environ Pollut. 135:313-322.

Peiter E, Montanini B, Gobert A, Pedas P, Husted S, Maathuis FJ, Blaudez D, Chalot M, Sanders D (2007) A secretory pathway-localized cation diffusion facilitator confers plant manganese tolerance. Proceed Natl Acad Sci USA. 104:8532-8537.

Pittman J (2005) Managing the manganese: molecular mechanisms of manganese transport and homeostasis. New Phytol. 167:733-742.

Prado RM (2008) Nutrição de plantas. Editora UNESP, São Paulo.

Puga AP, Prado RM, Melo DM, Guidi IM, Ortega K, Cardoso SS, Almeida TB (2011) Effects of manganese on growth, nutrition and dry matter production of plants of Brachiaria brizantha (cv. MG4) in greenhouse conditions. Rev Ceres. 58:811-816.

Reis LS, Ramos AA, Camargo AS, Oba E (2014) Effect of manganese supplementation on the membrane integrity and the mitochondrial potential of the sperm of grazing nelore bulls. Anim Reprod Sci. 150:1-6.

Saidi I, Nawel N, Djebali W (2014) Role of selenium in preventing manganese toxicity in sunflower (Helianthus annuus) seedling. S Afr J Bot. 94:88-94.
Santos HG, Jacomine PKT, Anjos LHC, Oliveira VA, Lumbreras JF, Coelho MR, Almeida JA, Cunha TJF, Oliveira JB (2013) System brazilian of soil classification. Centro Nacional de Pesquisa do Solo, Embrapa Solos, Rio de Janeiro.

Schmidt SB, Pedas P, Laursen KH, Schjoerring JK, Husted S (2013) Latent manganese deficiency in barley can be diagnosed and remediated on the basis of chlorophyll a fluorescence measurements. Plant Soil. 372:417-429.

Shenker M, Plessner OE, Tel-Or E (2004) Manganese nutrition effects on tomato growth, chlorophyll concentration, and superoxide dismutase activity. J Plant Physiol. 161:197-202.

Siddiqi LM, Glass ADM (1981) Utilization index: a modified approach to the estimation and comparison of nutrient utilization efficiency in plants. J Plant Nut. 4:289-302.

Smith KA, Paterson JE, (1990) Manganese and cobalt. In: Alloway, BJ (Ed.) Manganese and cobalt. John Wiley \& Sons, New York.

Swiader JM, Chyan Y, Freiji FG (1994) Genotypic differences in nitrate uptake and utilization efficiency in pumpkin hybrids. J Plant Nut. 17:1687-1699.

Sylvestre TB, Kuhnen F, Silva ER, Martins PES, Galatti FS, Prado RM (2012) Response tanzania grass to application of manganese. Biosc J. 28:684-691.

Teixeira IR, Borém A, Araújo GAA, Andrade MJB (2005) Teores de nutrientes e qualidade fisiológica de sementes de feijão em resposta à adubação foliar com manganês e zinco. Bragantia. 64(1):83-88.

Vitti GC, Oliveira DB, Quintino TA (2006) Micronutrientes na cultura da cana-de-açúcar. In: Segato SV, Pinto AS, Jendiroba E, Nóbrega JCM. Atualização em produção de cana-de-açúcar. CP2, Piracicaba.

Wang HH, Tao F, Peng XX, Yan ML, Zhou PL, TANG XK (2009) Ameliorative effects of brassinosteroid on excess manganese-induced oxidative stress in Zea mays L. leaves. Agri Sci China. 8:1063-1074.

Yasuor H, Firer M, Beit-Yannai E (2015) Protective structures and manganese amendments effects on antioxidant activity in pepper fruit. Sci Hortic. Amsterdam. 185:211-218. 